TEACHING TACTIC

\title{
A Self-Care Journal for the Religious Studies Classroom
}

\author{
Anthony Keddie \\ University of British Columbia
}

\section{The context}

This strategy was developed at a large public research university for students in lowerlevel introductory courses like "Introduction to Western Religions" and "Scriptures of the Near East." It has also been used effectively in upper-level New Testament courses.

\section{The pedagogical purpose}

For many students, especially those from conservative religious backgrounds, the academic study of religion can be alienating, confusing, and depressing. In a religion course in a public university setting, students can often feel that their own religious convictions are stifled and disregarded. This tactic resists the alienating tendency of religious studies courses by recognizing students' emotional struggles as valid and providing a nonjudgmental mechanism for supporting students as they work through the ways that a course challenges their religious or non-religious convictions.

\section{Description of the strategy}

At the beginning of the semester, I ask students to initiate a Self-Care Journal. At least once every two weeks, I reserve five to ten minutes of class time for them to write in this private journal, which is not read or graded. It can be either hand-written or digital, but all entries should be recorded in the same place. I underscore that this exercise in self-care allows a safe space for students to explore how learning critical approaches to religion makes them feel about their own religious identity (and its intersections with race, ethnicity, gender, sexuality, etc.).

I use prompts like the following, which can be adjusted to align with course content and methods:

- How does your understanding of religion affect your life?

- What challenges does your religious or non-religious worldview present for your learning in a course like this?

- What self-care strategies can you employ when you encounter material that makes you angry, uncomfortable, or sad?

After writing certain entries, I invite students to share with small groups or the full class so that they can see how their peers are grappling with some of the same issues. This activity can also be prefaced by a few minutes of silent breathing exercises to help students focus their thoughts.

\section{Why it is effective}

Scholarship on learning ${ }^{1}$ shows that college-aged students' intellectual development is interdependent on their emotional and social development. By encouraging students to reflect on how their learning about religion affects their general wellbeing, this exercise fosters students' awareness of their emotional and mental health and encourages them to incorporate strategies of self-care into their daily lives. Scholarship ${ }^{2}$ also stresses that effective teaching builds on students' prior knowledge. This tactic enables students to activate their prior knowledge in concert with critical inquiry.

1 https://www.wiley.com/en-us/How+Learning+Works\%3A+Seven+Research+Based+Principles+for+Smart+Teaching-p-9780470484104

2 https://www.routledge.com/From-the-Laboratory-to-the-Classroom-Translating-Science-of-Learning-for/Horvath-Lodge-Hattie/p/book/9781138649644 